\title{
DIE IMPAK VAN METODOLOGIE OP DIE VERSTAAN VAN DIE NUWE TESTAMENT*
}

\author{
D.F. Tolmie ${ }^{1}$
}

\section{ABSTRACT \\ THE EFFECT OF METHODOLOGY ON THE INTERPRETATION OF THE NEW TESTAMENT}

During the previous century many new methods for interpreting the New Testament were developed. In this article it is asked if new methods always enable better insight into the New Testament. Although it is conceded that this is not always the case, it is argued that the correct application of new methods can indeed facilitate new insights into the New Testament. This is then illustrated by examples from the narratological analysis of the Fourth Gospel and the rhetorical analysis of the Letter to the Galatians.

\section{INLEIDING}

Die pas afgelope eeu is gekenmerk deur merkwaardige vooruitgang in al die teologiese vakdissiplines. In die geval van die Nuwe-Testamentiese wetenskap was een van die opvallende verskynsels die groot aantal nuwe eksegetiese metodes wat beskikbaar geraak het. Aan die begin van die vorige eeu was 'n groot aantal van die leesstrategieë wat NuweTestamentici deesdae vanselfsprekend as deel van hulle instrumentarium beskou, nog nie beskikbaar nie. As voorbeelde hiervan kan 'n mens vormkritiese, redaksiekritiese, strukturalistiese, sosiologiese, narratologiese, leser-georiënteerde en ideologies-kritiese lees van NuweTestamentiese tekste noem. ${ }^{2}$ In Suid-Afrika het ons die vermenig-

* 'n Verwerkte weergawe van professorale intreerede aan die Departement Nuwe Testament aan die Universiteit van die Vrystaat, gelewer op 9 Junie 2004.

1 Prof. D. F. Tolmie, Departementshoof: Departement Nuwe Testament, Fakulteit Teologie, Universiteit van die Vrystaat. E-pos: tolmief.hum@mail.uovs.ac.za

2 Kyk Brown (1997:20-29) vir 'n kort oorsig van 'n hele aantal metodes wat deur Nuwe-Testamentici gebruik word. 
vulding van metodes waarskynlik nog hewiger beleef as in die res van die wêreld — soos die oorsigte van Du Toit (1993a:503-514; 1993b: 787-809 - veral pp. 790-792) en Van Zyl (2000:169-236) toon. Van Zyl (2000:205) is egter korrek as hy sê dat die Methodenstreit waardeur SA biblioloë gegaan het darem een positiewe gevolg gehad het, naamlik dat dit vir ons 'n metodologiese sensitiwiteit aangeleer het; dat ons deeglik daarvan bewus is dat leesresultate nie sommer net vanself verskyn nie, maar dat dit gekoppel is aan die metode of leesstrategie wat bewustelik of onbewustelik gevolg word.

'n Belangrike vraag wat ons egter behoort te vra, is of al die nuwe metodes inderdaad nuwe lig gewerp het op die verstaan van die Nuwe Testament. 'n Mens moet dadelik toegee dat dit in baie gevalle nie gebeur het nie. Dunn (1997:12) het byvoorbeeld tereg kritiek uitgespreek op die soms onnodig ingewikkelde analises van Paulus se briewe:

And as for some of the elaborate structures which have been proposed for Paul's letters, one might simply observe that there seems to be an inverse ratio between the length of proposed chiasms in an individual letter and the light they shed on either the argument or its point.

Aan die ander kant is dit egter beslis ook waar dat daar wel baie positiewe gevolge was. Dit is inderdaad so dat 'n skat van nuwe insigte voortgespruit het uit die aanwending van die talle nuwe metodes wat tot beskikking van eksegete gekom het. In sommige gevalle het dit verrassende nuwe perspektiewe op Nuwe-Testamentiese tekste tot gevolg gehad. In ander gevalle het dit ons geleer om meer genuanseerd oor sekere aspekte van die Nuwe Testament te praat. As 'n mens byvoorbeeld eers een maal deur die bril van die vorm- en redaksiekritiek na die Evangelies gekyk het, dink jy vir altyd anders oor hulle totstandkoming. Inderdaad, nuwe metodes lei tot nuwe perspektiewe! Dit is dan ook waar die fokus van hierdie artikel val: die impak van metodologie op die verstaan van die Nuwe Testament. Ek wil aantoon hoe die gebruik van bepaalde metodes tot nuwe insigte in die Nuwe Testament kan lei. Om dít te demonstreer, het ek het twee leesstrategieë gekies, naamlik narratologiese en retoriese lees van tekste. Ek het nie hierdie twee benaderings gekies omdat ek dink dat dit die beste beskikbare leesstrategieë is nie, maar wel omdat ek al heelwat navorsing daaroor gedoen het. 


\section{2. 'N NARRATOLOGIESE LEES VAN DIE JOHANNESEVANGELIE}

Vanaf die vyftigerjare van die vorige eeu het navorsers baie tyd spandeer aan die ontrafeling van die ontstaansproses wat die Johannesevangelie deurloop het. Die metodes wat op daardie stadium die toneel oorheers het, was die bronne- en redaksiekritiek. Die belangrikste bydraes wat vanuit hierdie perspektief gelewer is, het gekom van bekende Nuwe-Testamentici soos Bultmann, Haenchen, Wilkens, Schnackenburg, Brown, Fortna, Becker en Teeple. ${ }^{3}$ Hulle navorsing was primêr gerig op die identifisering van die verskillende bronne wat deur die outeur en redaktors van dié Evangelie gebruik is en die redaksiefases waardeur dié Evangelie gegaan het. Dié tipe navorsing het egter mettertyd 'n doodloopstraat bereik. Daar is twee redes daarvoor. Enersyds het daar spoedig 'n hele aantal kompeterende samestellingsteorieë ontstaan waarvan die een op die oog af net so goed soos die ander was. Andersyds het Johanneskenners al hoe meer skepties begin raak oor die selfversekerdheid waarmee bronne geïdentifiseer en presies gerekonstrueer is. Daar was wel een blywende winspunt uit al dié navorsing, naamlik die insig dat die Johannesevangelie 'n lang en komplekse ontstaansproses van ongeveer dertig tot veertig jaar deurloop het en dat daar naas die oorspronklike outeur ook redaktors in die proses betrokke was.

Vanweë die fokus van die bronne- en redaksiekritiek het navorsers egter nooit veel aandag aan die finale gestalte van die Johannesevangelie gegee nie. Die situasie het egter verander met die koms van die narratologiese lees van die verhalende tekste in die Ou en Nuwe Testament. In die geval van die Johannesevangelie was die baanbreker Culpepper (1983) wat die eerste persoon was wat 'n volledige narratologiese analise van die Johannesevangelie gepubliseer het. Naas hom het Nuwe-Testamentici soos Staley (1988) en Stibbe (1992; 1993) ook belangrike bydraes gelewer.

Wanneer ' $n$ mens die Johannesevangelie vanuit narratologiese hoek lees, val die klem op die feit dat dit 'n verhaal is met al die ken-

3 Kyk Du Rand (1990:84-93) vir 'n vollediger oorsig van die bydraes van elkeen van hierdie Johanneskenners. 
merkende elemente wat in enige verhaal voorkom, naamlik implisiete outeur en implisiete leser, verteller en aangesprokene, fokalisasie, karakterisering, gebeure, tyd en ruimte. Wanneer 'n mens die Johannesevangelie narratologies lees, ontken 'n mens nie noodwendig die feit dat die Evangelie 'n lang en ingewikkelde ontstaansproses deurloop het nie. Die fokus val egter op 'n ander saak, naamlik die feit dat dit uiteindelik in die finale fase 'n geïntegreerde verbaal gevorm het en dat die finale gestalte van die Evangelie as verhaal ernstig geneem moet word. ${ }^{4}$ Myns insiens is een van die winspunte van 'n narratologiese lees van die Johannesevangelie die feit dat dit 'n mens dwing om die verhaal as ' $n$ geheel te lees en dan verbande in die teks te lê wat vanweë die perspektief van bronne- en redaksiekritiek nie moontlik was nie. Ek wil dit illustreer aan die hand van twee voorbeelde van karakterisering in die Johannesevangelie, naamlik die karakterisering van God en van Petrus.

Daar is verskeie moontlike prosedures wat gevolg kan word as 'n mens karakterisering ondersoek, ${ }^{5}$ maar die een wat in hierdie geval die bruikbaarste is, is die prosedure van Chatman (1978:119-133). Sy benadering is gebaseer op die definisie van karakters in 'n narratiewe teks in terme van 'n versameling van karaktertrekke ("a paradigm of traits") wat met elke karakter geassosieer word. Onder 'n "karaktertrek" verstaan hy enige eienskap wat met 'n karakter tydens die ontvouing van die gebeure geassosieer word. Tydens die vertelproses onthul die implisiete outeur sekere karaktertrekke wat met elke karakter geassosieer word. Soos wat die verhaal ontvou, word reeds bekende karaktertrekke herbevestig, nuwe karaktertrekke onthul of reeds bekende karaktertrekke deur ander vervang. Gesien vanuit die perspektief van die implisiete leser, verloop die proses as volg: hy/sy assosieer met elke karakter in die verhaal 'n eie "lysie" van karaktertrekke wat telkens bevestig, uitgebrei of verander word wanneer die karakter verder-aan in die verhaal weer voorkom.

4 Vanweë die ingewikkelde ontstaansproses wat die Johannesevangelie deurloop, moet 'n mens egter ook besef dat daar aspekte in dié Evangelie is wat vanuit narratologiese perspektief nie sin sal maak nie omdat dit die gevolg is van 'n baie komplekse ontstaansproses.

5 Kyk Tolmie (1999:52-57) vir 'n vollediger uiteensetting van die verskillende maniere waarop karakterisering ondersoek kan word. 
2.1 Die karakterisering van God in die Johannesevangelie 'n Narratologiese kyk na die manier waarop God in die Johannesevangelie uitgebeeld word, lei tot interessante nuwe perspektiewe omdat 'n mens dan 'n patroon raaksien wat nie deur ander metodes blootgelê word nie. Dié patroon ontwikkel stelselmatig soos die plot van die Evangelie ontvou.

Die Proloog (Joh. 1:1-18) dien as 'n "inventaris" vir die implisiete leser omdat dit aan hom/haar 'n deeglike greep op die teologiese perspektief van die Evangelie bied en 'n hele aantal belangrike temas uitlig voordat die gebeure self begin. Ten opsigte van die karakterisering van God, bied die Proloog sommer alreeds heel aan die begin aan die implisiete leser 'n stewige greep op die wyse waarop God in die res van die verhaal uitgebeeld sal word. Twee sake is veral van belang. Eerstens word die implisiete leser gewys op die besondere ver-

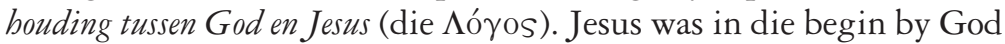
en is self God (1:1). Verder is dit duidelik dat God die koms van Jesus geïnisieer het omdat Hy die Doper gestuur het (1:6). In 1:14 en 18 volg die hoogtepunt as God as Jesus se Vader beskryf word en dié intieme verhouding aangrypend uitgedruk word wanneer die implisiete leser hoor dat Jesus, self die Unieke, God, in die boesem van die Vader is. Tweedens word die implisiete leser se aandag ook gerig op die moontlikheid van 'n besondere verbouding tussen God en mense. Dit gebeur in verse 12-13. Hier sê die verteller dat mense

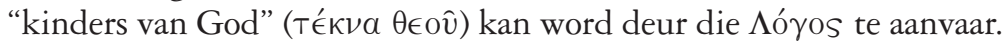
Dat dit nie oor 'n normale soort verhouding gaan nie, is duidelik uit die metafoor wat gebruik word, naamlik dat hulle uit God "gebore word". Dit is ook opvallend dat, alhoewel kindskap van God duidelik

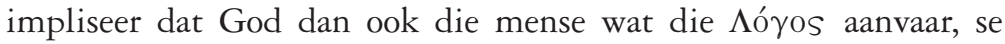
"Vader" word, die verteller dit nie eksplisiet noem nie. In die Proloog word die term "Vader" dus gereserveer vir die verhouding tussen God en Jesus.

Johannes 1:19-12:50 handel oor die gebeure in die verhaalwêreld voordat Jesus se verheerliking begin. Ten opsigte van die karakterisering van God in hierdie deel van die verhaal is die opvallendste dat dit gedomineer word deur die verhouding tussen God en Jesus. Meer as $80 \%$ van die verwysings na God het op een of ander manier te doen 
met Jesus. Die uitstaande karaktertrek wat met God in hierdie deel geassosieer word, is die feit dat Hy die Vader van Jesus is en dat Jesus sy Seun is. Dit word oor en oor beklemtoon en lei mettertyd tot groot ontsteltenis en teëkanting onder die Jode. Wat veral opvallend is, is dat God se Vaderskap deurgaans beperk word tot Jesus. God word dus uitsluitlik uitgebeeld as die Vader van Jesus. Nie een van die ander karakters in die verhaalwêreld word ooit verbind aan God se Vaderskap nie. Die Jode maak wel daarop aanspraak dat God hulle Vader is (8:41), maar uit die verhaalgang is dit duidelik dat hulle aanspraak vals is. ${ }^{6}$

Daar word in hierdie deel van die Evangelie ook aandag gegee aan die moontlike verhouding tussen God en mense. So hoor die implisiete leser byvoorbeeld in Johannes 3 van God se Koningskap - 'n tema wat dan ontwikkel word in terme van die verhouding tussen God en mense as die geboortemetaforiek weer belangrik word. In dieselfde hoofstuk word 'n ander karaktertrek van God uitgelig, naamlik dat Hy die wereld liefhet (3:16-21). Twee ander karaktertrekke van God wat ook in hierdie hoofstuk na vore kom, is die feit dat Hy die standaarde stel waaraan mense moet voldoen $(3: 21)$ en dat Hy mense sal straf wat ongehoorsaam aan die Seun is (3:36). In 6:43-46 word 'n verdere karaktertrek van God uitgelig, naamlik dat dit $\mathrm{Hy}$ is wat mense na Jesus trek.

Die oorheersende patroon in die karakterisering van God in 1:1912:50 is egter die klem op die verhouding tussen God en Jesus veral die feit dat God die Vader van Jesus is. In die enkele gevalle waar die verteller verwys na die verhouding tussen God en die mensdom, val die klem op die feit dat Hy die Een is wat dit vir mense moontlik makk om 'n besondere verhouding met Hom te hê. In die Proloog is hierdie verhouding beskryf as "kindskap van God" en is die verwag-

6 Afgesien van die karakterisering van God in terme van sy Vaderskap van Jesus, word ook enkele ander uitdrukkings gebruik om die verhouding tussen God en Jesus te belig, waarvan die feit dat God vir Jesus gestuur het, die meeste voorkom. Ander uitdrukkings wat ook gebruik word om die verhouding tussen God en Jesus te belig, is dat Jesus die Lam van God is (1:29, 35); dat Hy 'n Leermeester is wat van God kom (3:2); die woorde van God spreek (3:34), die gawe van God is (4:10); deur God beseël is (6:27) en die Heilige van God is (6:69). 
ting geskep dat mense in die verhaalwêreld hierdie verhouding sou ervaar. In 1:19-12:50 realiseer hierdie verwagting egter nog nie.

In Johannes 13-21 vind ons die klimaks en afloop van die gebeure. In 13:1-17:26 vertel die verteller wat alles die aand voor die kruisiging gebeur het. Die oorheersende perspektief in hierdie vyf hoofstukke is die klem op dissipelskap, d.w.s. wat dit beteken om 'n volgeling van Jesus te wees. Die situering verskil heelwat van die vroeëre deel van die verhaal aangesien die implisiete outeur die gebeure nou binne 'n besondere atmosfeer plaas: Jesus en sy dissipels is alleen saam by 'n maaltyd, Hy was hulle voete, neem afskeid van hulle, buite in die donker is sy vyande besig om planne te beraam om Hom gevange te neem ... Verder situeer die implisiete outeur die gebeure ook duidelik binne die verheerliking van Jesus (12:23 en 13:1) — die groot draaipunt in die Evangelie.

Ten opsigte van die karakterisering van God vind 'n mens min of meer dieselfde patroon as in die eerste deel van die Evangelie deurdat Hy nog steeds primêr in terme van verhoudings gekarakteriseer word. Weer eens is daar 'n oorvloed van verwysings na die verhouding tussen God en Jesus. Die volgende lys bevestig dit:

- Die Vader gee alles oor aan Jesus (13:3; 17:2);

- Die Vader het vir Jesus gestuur $(13: 3,20 ; 15: 21 ; 16: 5,28,30$; 17:3, 8, 18, 25);

- Die Vader verheerlik vir Jesus (13:31, 32; 17:1, 5, 22);

- Die Vader openbaar Homself deur Jesus (14:6-11; 17:6, 11, 14, 26);

- $\quad$ Die Vader is in Jesus (14:10-11; 14:20);

- Die Vader sê vir Jesus wat om te doen en te sê (14:10, 24, 31; 15:10, 15);

- Die Vader voldoen aan Jesus se versoeke (14:16);

- Die Vader is groter as Jesus (14:28);

- Die Vader het Jesus lief (15:9; 17:23, 26);

- Die Vader gee mense aan Jesus $(17: 6,9)$;

- Die Vader en Jesus is een (17:10, 11, 21-22).

Nie een van hierdie karaktertrekke is nuut nie en dus kan 'n mens sê dat daar nie werklik enige ontwikkeling in die karakterisering van God in terme van sy verhouding teenoor Jesus is nie. Die implisiete 
outeur herbevestig dus net die karaktertrekke wat reeds aan die implisiete leser geopenbaar is.

Ten opsigte van die karakterisering van God in terme van sy verhouding teenoor mense is daar egter 'n belangrike ontwikkeling. Nie alleen kry hierdie aspek baie meer aandag as in die vorige deel van die Evangelie nie; nou word daar baie klem geplaas op die voordele wat hierdie verhouding vir mense inhou. Kyk na die volgende voorbeelde:

- Daar is oorgenoeg plek vir hulle in sy "huis" (14:2);

- Hy sal die Parakleet na hulle stuur (14:16, 26; 15:26);

- Hy sal lief wees vir hulle $(14: 21,23 ; 16: 27)$;

- Hy sal kom en by hulle bly (14:23);

- Hy sal die wingerdlote snoei sodat hulle meer vrug sal dra $(15: 2)$;

- Hy sal gee wat hulle vra (15:16; 16:23);

- Hy sal hulle beskerm teen die Bose (17:15);

- Hy sal hulle help om één te wees (17:21-22).

Wat dus gebeur, is dat kindskap van God, wat in die Proloog en in Johannes 1:19-12:50 as 'n moontlikheid uitgebeeld word, nou 'n realiteit word. Die implisiete outeur word gekonfronteer met dalk moet 'n mens liewer sê "ingetrek in" — die besondere intieme atmosfeer tussen God, Jesus en die dissipels, met die dissipels wat uitgebeeld word as 'n groep mense wat reeds deel het aan die unieke verhouding met God. Daar is egter een aspek wat nog kortkom: God word nog nie eksplisiet as hulle Vader gekarakteriseer nie. Dit gebeur eers in die laaste gedeelte van die verhaal.

Johannes 18:1-21:25 vorm die ontknoping en afloop van die verhaal. In hierdie gedeelte verwys die verteller slegs 'n paar keer direk na God, naamlik in $18: 11 ; 19: 7 ; 20: 17,21,28,31$ en 21:19. In die meeste gevalle word verwys na karaktereienskappe van God wat reeds vroeër in die Evangelie geopenbaar is. ${ }^{7}$ Myns insiens vind die belang-

7 Die karaktereienskappe wat genoem word, fokus almal op die verhouding tussen God en Jesus, naamlik dat Jesus gehoorsaam is aan die Vader (18:11); dat Hy die Seun van God is $(19: 7 ; 20: 31)$; dat Hy deur die Vader gestuur is (20:21) en dat Hy gelyk aan God is (20:28). 
rikste ontwikkeling in die karakterisering van God egter in 20:17 plaas waar Jesus vir die dissipels sê: "Ek vaar op na my Vader en julle Vader, na my God en na julle God". Wanneer hierdie uitspraak gelees word teen die wyse waarop God in die res van die Evangelie in terme van sy verhouding teenoor mense gekarakteriseer word, is die ontwikkeling opvallend. Dit is die eerste keer in die Evangelie dat God se Vaderskap aan karakters anders as Jesus gekoppel word! Hierdie vers bied aan die implisiete leser dit waarop hy/sy sedert die Proloog gewag het; as't ware die laaste stukkie van die legkaart: God is nie net die Vader van die Jesus nie, maar ook die Vader van die dissipels. Hoekom nóú eers? Hoekom eers ná die verheerliking van Jesus begin het? Waarskynlik omdat die implisiete outeur 'n belangrike teologiese grondlyn wil beklemtoon: kindskap van God kan slegs 'n realiteit in mense se lewens word op grond van die verheerliking van Jesus, die Seun van God. Op grond van dit wat tydens sy verheerliking gebeur het, kon God se Vaderskap via Jesus uitgebrei word na die gelowiges.

Om saam te vat: deur middel van 'n narratologiese lees van die Johannesevangelie kan 'n mens nie net 'n interessante patroon in die karakterisering van God raaksien nie; 'n mens kan ook 'n belangrike teologiese moment raaksien wat andersins verborge sou gebly het.

\subsection{Die karakterisering van Petrus in die Johannesevangelie}

Oor die rol van Petrus in die Johannesevangelie is daar al baie navorsing gedoen $^{8}$ — ook vanuit narratologiese perspektief. ${ }^{9}$ Uit navorsing wat reeds in dié verband gedoen is, is dit duidelik dat daar tot 'n groot mate konsensus is oor 'n hele aantal aspekte wat kenmerkend van die Petrusfiguur in die Johannesevangelie is, byvoorbeeld die leierskapsrol wat hy speel, sy gewilligheid om Jesus te volg en te dien, sy impulsiwiteit, die komplekse verhouding tussen hom en die Geliefde Dissipel en sy herderlike rol. Dit is nie my bedoeling om hier 'n volledige analise van die karakterisering van Petrus in die Johannesevangelie te bied nie. Ek wil die aandag spesifiek vestig op een aspek waar daar

8 Enkele voorbeelde: Brown et al. (1973:114-129); Maynard (1984) en Quast (1989).

9 Na my mening is die beste narratologiese studie van Petrus in die Johannesevangelie die een van Wiarda (2000; hy ondersoek al vier Evangelies). Kyk ook Culpepper (1983:120-121) en Stibbe (1993). 
vanuit die narratologiese lees van die Johannesevangelie moontlik verdere lig op die rol van Petrus in die Johannesevangelie gewerp kan word. Dit het te doen met een van die aspekte wat reeds hierbo vermeld is, naamlik Petrus se herderlike rol. Eksegete verbind hierdie aspek gewoonlik tereg aan Johannes 21 waar Jesus vir Petrus drie keer 'n opdrag gee om na sy skape om te sien. Myns insiens kom hierdie aspek alreeds vroeër in die Evangelie voor en kan 'n mens - soos in die geval van die karakterisering van God - 'n lyn aantoon wat dwarsdeur die Evangelie loop en dan in die laaste deel van die verhaal ' $n$ klimaks bereik.

Ek begin met 'n oorsig van die gevalle waar die implisiete outeur die implisiete leser se aandag op Petrus vestig:

1:40-42: Simon word een van Jesus se dissipels en sy naam word verander na Petrus;

6:67-69: Petrus bely dat Jesus die Heilige van God is;

13:6-11: Jesus was Petrus se voete;

13:23-26: Petrus vra die Geliefde Dissipel om vir Jesus te vra wie Hom gaan verraai;

13:36-38: Jesus sê dat Petrus hom gaan verloën;

18:10-11: Petrus kap Malgus se oor af tydens Jesus se inhegtenisname;

18:15-16: 'n Ander dissipel (= die Geliefde Dissipel?) help vir Petrus om by die binneplaas van die Hoëpriester in te gaan; 18:17-18, 25-27: Petrus verloën Jesus drie maal;

20:2-10: Petrus en die Geliefde Dissipel by Jesus se leë graf;

21:1-23: Petrus se optrede tydens en na die wonderlike visvangs.

In die eerste helfte van die Evangelie word Petrus net by twee geleenthede individueel gekarakteriseer. In beide gevalle beklemtoon die implisiete outeur sy leierskapsrol. Tydens sy roeping as dissipel (1:40-42) vermeld die verteller die feit dat Jesus aan hom die naam "Petrus" gee - 'n naam wat as gevolg van die assosiasie met die Griekse woord vir "rots" alreeds op Petrus se belangrike rol onder die dissipels en later in die vroeë kerk sinspeel (Busse 2002:83; Cullmann 1970:18-28). In die tweede geval word sy leidende rol duidelik vergestalt as Jesus aan die twaalf vra of hulle nie ook wil weggaan nie en Petrus namens hulle as segsman optree met die woorde: "Here, na 
wie toe sal ons gaan? U het die woorde van die ewige lewe" (6:67-69). Die prentjie wat die implisiete leser van Petrus aan die einde van Jesus se openbare bediening (1:19-12:50) het, word dus grootliks gedomineer deur die perspektief dat Petrus as leiersfiguur onder die dissipels optree.

Die volgende keer wanneer Petrus weer as individu na vore tree, is tydens die gebeure die aand voor die kruisiging (13). Tydens die laaste maaltyd val die fokus by drie geleenthede op hom: wanneer hy aanvanklik weier dat Jesus sy voete was en daarna heeltemal oorboord gaan en vra dat Hy ook sy hande en sy kop was; wanneer hy vir die Geliefde Dissipel met 'n kopknik beduie om vir Jesus te vra wie hom gaan verraai; en wanneer hy van Jesus moet hoor dat hy Hom sal verloën. Vir ons doeleindes ${ }^{10}$ is dit belangrik om raak te sien dat Petrus in al drie gevalle gekarakteriseer word as die een wat as die leier van die dissipels die inisiatief neem. In die eerste geval (die voetewassing) verwoord hy waarskynlik 'n gevoel wat in al die dissipels se harte leef; in die tweede geval (die aankondiging van die verraad) neem hy die inisiatief om uit te vind wie die verraaier is - 'n behoefte wat waarskynlik by al die dissipels (uitgesonderd Judas!) leef; en in die derde geval reageer hy namens die dissipels op Jesus se aankondiging dat Hy weggaan deur Hom direk te vra waarheen Hy gaan.

Die aankondiging van Petrus se verraad moet van nader bekyk word, aangesien daar myns insiens 'n verband is met iets wat vroeër in die Evangelie gebeur - iets wat tot sover nie genoegsaam verreken is in die studies oor Petrus se rol in die Johannesevangelie nie. Om dit raak te sien, moet 'n mens baie noukeurig kyk na die gesprek tussen Jesus en Petrus (13:36-38).

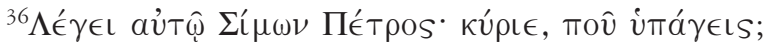

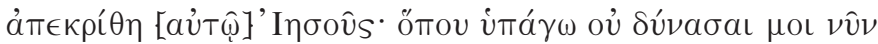

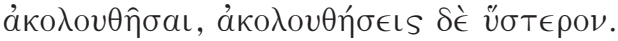

10 Die implisiete outeur gebruik natuurlik hierdie drie gebeure om ook verskeie ander karaktertrekke van Petrus aan die implisiete leser deur te gee, onder andere sy impulsiwiteit, sy onvermoë om Jesus te verstaan, dat hy nie so naby as die Geliefde Dissipel aan Jesus was nie, en sy gewilligheid om Jesus te volg. Vir die doel van hierdie artikel is hierdie karaktertrekke egter nie belangrik nie. 


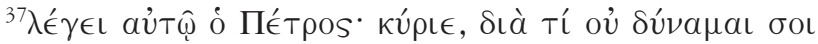

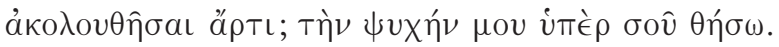

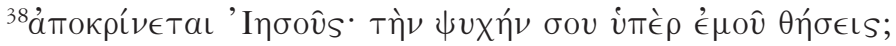

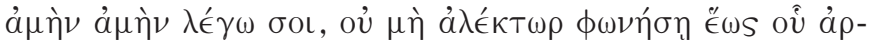

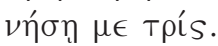

Vanuit narratologiese perspektief is dit belangrik om te besef dat een van die maniere wat die implisiete outeur tot sy beskikking het om karakters op indirekte wyse te karakteriseer, is wat hulle sê en boe hulle dit sê. ${ }^{11}$ As 'n mens na die woorde kyk wat Jesus en Petrus gebruik, is dit opvallend dat hulle altwee begrippe gebruik wat 'n prominente rol speel in die gedeelte oor die Goeie Herder (Joh. 10), ${ }^{12}$

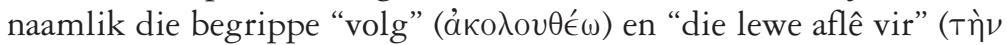

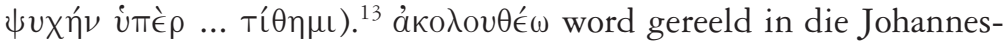
evangelie gebruik ${ }^{14}$ - meestal as 'n manier om dissipelskap aan te dui (Barrett 1978:180; Schnackenburg 1979:308). In die gedeelte oor die Goeie Herder word hierdie woord twee keer gebruik as gesê word dat die skape Hom volg (10:4,5). Dit kom weer later in 10:27 voor wanneer Jesus sê dat sy skape sy stem hoor en Hom volg. In 12:26 volg 'n verdere belangrike uitspraak wanneer Jesus sê dat iemand wat Hom wil dien, Hom moet volg.

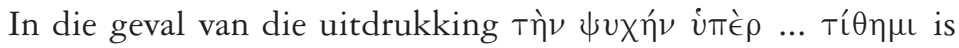
dit opvallend dat Petrus presies dieselfde woorde gebruik as wat Jesus gebruik het toe Hy gesê het dat die Goeie Herder sy lewe vir die skape aflê (10:11). Dit is verder opvallend dat dit slegs in die Johannes-

11 Rimmon-Kenan (1983:63) stel dit as volg:

A character's speech, whether in conversation or as silent activity of the mind, can be indicative of a trait or traits both through its content and through its form.

12 Kyk Van der Watt (2000:177) vir 'n goeie bespreking van die metaforiek in Johannes 10. In sy gedetailleerde analise wys hy hoe twee sentrale aspekte (Jesus as "deur" en as "Goeie Herder") deur 'n hele reeks metafore, vergelykings en klimaktiese beskrywings op 'n komplekse wyse ontvou word.

13 Kommentatore verwys dikwels na die feit dat Petrus dieselfde woorde as Jesus gebruik as hy sê dat hy sy lewe vir Jesus sal aflê, maar hulle besef nie die implikasies hiervan nie. Kyk byvoorbeeld Barrett (1978:453) en Brown (1984:616).

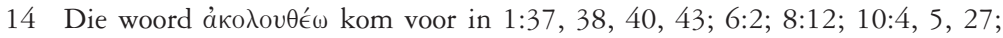
$11: 31 ; 12: 26 ; 13: 36(2 x), 37 ; 18: 15 ; 20: 6$; en $21: 19,20,22$. 
evangelie is dat Petrus die uitdrukking "my lewe aflê vir" gebruik as hy onderneem om nie vir Jesus in die steek te laat nie. ${ }^{15}$

Is dit toevallig dat sowel Jesus as Petrus begrippe gebruik wat groot prominensie verkry het toe Jesus oor die Goeie Herder gepraat het? Myns insiens nie. Dit lyk of die implisiete outeur deur hierdie karakterisering alreeds Petrus se leidende rol in terme van herderskap wil belig, maar dan in die sin dat Petrus in hierdie stadium in die gang van gebeure nog nie by magte is om werklik 'n herder te wees nie. In die lig van Johannes $10 \mathrm{kan}$ 'n mens die gesprek tussen Jesus en Petrus as volg lees: Die aand voordat die Goeie Herder sy lewe vir die skape aflê, sê die Goeie Herder (wat sy skape ken) vir Petrus: "Waarheen Ek, die Goeie Herder, gaan, kan jy, Petrus, een van my skape, My nie volg nie, maar jy sal My later volg." As Petrus voortvarend antwoord: "Here, waarom kan ek U nie nou volg nie? Ek sal my lewe vir U aflê!", sê hy eintlik vir Jesus: "Ek is nie net bereid om $\mathrm{U}$ te volg soos 'n skaap sy herder volg nie; soos 'n goeie herder sal ek my lewe vir $U$ aflê!"

Dit is waarskynlik nie die bedoeling van die implisiete outeur dat Petrus inderdaad self verstaan wat hy sê nie. Die gebruik van die tegniek van misverstand in hierdie en ander hoofstukke in die Evangelie spreek daarteen. Die karakterisering van Petrus is waarskynlik ironies bedoel in die sin dat 'n karakter iets sê wat hy self nie begryp nie; as't ware iets ten koste van homself sê. Dit is asof die implisiete outeur met 'n oogknip vir die implisiete leser sê: "Kyk wat doen Petrus hier! Hy kan nie eens 'n goeie skaap wees nie, maar hy wil 'n goeie herder wees!"

In Johannes 18 wys die implisiete outeur hoe Petrus op 'n tragiese manier faal. In plaas daarvan om sy eie lewe af te lê, probeer hy 'n lewe neem as hy Malgus met die swaard aanval (18:10-11). 'n Rukkie later begin hy wel saam met ' $\mathrm{n}$ ander dissipel (die Geliefde Dissipel?) vir Jesus volg (18:15), maar dit duur nie lank nie. Terwyl die Goeie

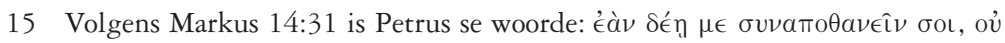

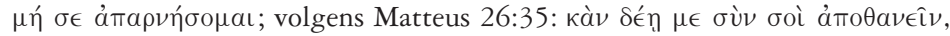

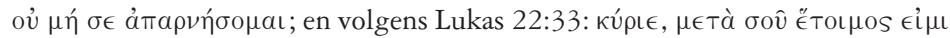

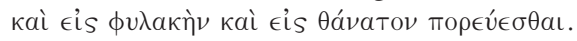


Herder gereed maak om sy lewe vir sy skape af te lê, ${ }^{16}$ verloën Petrus Hom drie maal (18:17-18, 25-27). Hy lê nie sy lewe af vir Jesus nie, maar veg om sy eie lewe.

Gelukkig is dit nie die einde van die verhaal nie. In Johannes 21 word Petrus deur Jesus herstel en funksioneer die herdermetaforiek weer eens. Nou word hy deur Jesus self as herder aangestel wanneer hy, wat drie keer vir Jesus verloën het, drie keer op die vraag moet antwoord of hy Hom liefhet. Die implisiete leser hoor hoe Petrus wat gefaal het as skaap en goeie herder, nou opnuut deur die ware Goeie Herder as herder aangestel word:

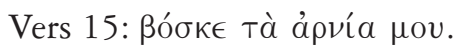

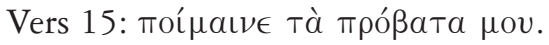

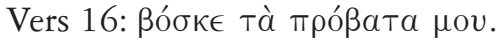

Dit is egter nie al nie. Jesus sê ook vir Petrus dat die onderneming wat hy gegee het om sy lewe vir Hom af te lê, wel waar sal word as hy sy hande sal uitsteek en iemand ander hom sal aantrek en hom sal bring waar hy nie wil wees nie - 'n sinspeling op sy marteldood (21:18-19). Dit eindig met Jesus se opdrag: "Volg my!" (21:19). As Petrus werklik 'n goeie herder vir Jesus se skape wil wees, moet hy aanhou om Jesus te volg!

Alhoewel die herder-metafoor net een aspek van die karakterisering van Petrus in die Johannesevangelie uitmaak, is dit nietemin 'n belangrike aspek. Indien my analise hierbo korrek is, help 'n narratologiese analise ' $n$ mens om 'n definitiewe patroon in die Evangelie te onderskei. Aanvanklik val die klem op Petrus se leidende rol onder die dissipels. Dan, ná die gedeelte oor Jesus as die Goeie Herder, verskuif die fokus na Petrus se eie poging om 'n goeie herder te wees. Hy is nie net bereid om vir Jesus te volg (soos 'n goeie skaap nie); soos 'n goeie herder sal hy selfs bereid wees om sy lewe vir Jesus af te lê. Daarna kom sy klaaglike mislukking as hy nie end-uit kan volg en sy lewe kan aflê nie. In die laaste hoofstuk kom die ommekeer: Jesus self herstel hom en maak van hom 'n goeie herder vir sy (= Jesus se!) skape - met die vooruitsig dat hy eendag wel sy lewe sal aflê soos 'n goeie herder betaam.

16 In sy analise van Johannes 18-19 toon Stibbe (1992:96-120) oortuigend aan watter belangrike rol die Goeie Herder-motief in hierdie hoofstukke speel. 
Net 'n mooi patroon? Nee, ek dink daar sit ten minste twee belangrike teologiese perspektiewe op wat ons in die moderne kerkopset "amp" noem. Eerstens, wie uit eie krag 'n herder vir Christus se skape probeer wees, kry dit gewoonlik nie reg nie. Werklike goeie herders word deur die opgestane Jesus self aangestel. Tweedens, wie werklik 'n goeie herder wil wees, moet aanhou om dié Goeie Herder te volg — self al kos dit die dood.

\section{3. 'N RETORIESE LEES VAN DIE BRIEF AAN DIE GALASIËRS}

In die geval van die Brief aan die Galasiërs was H. D. Betz die baanbreker wat 'n nuwe koers vir navorsers aangedui het toe hy weer opnuut die aandag gevestig het op die retoriese aard van hierdie Pauliniese brief. Na sy vroeëre navorsing in hierdie rigting (1975), het hy in 1979 'n volledige kommentaar oor Galasiërs gepubliseer. Die vertrekpunt van sy analise was dat Galasiërs 'n voorbeeld van die antieke "apologetiese briefgenre" is en daarom deur middel van die antieke Grieks-Romeinse retoriek en epistolografie geanaliseer kan word. Betz het beweer dat Galasiërs (as apologetiese brief) 'n voorbeeld van forensiese retoriek is omdat dit 'n fiktiewe situasie in 'n hofsaal veronderstel: Paulus is die aangeklaagde wat homself moet verdedig, sy opponente is die aanklaers en die ontvangers van die brief is die jurie.

Betz se nuwe benadering het ' $n$ stortvloed navorsing tot gevolg gehad. Sy analise het gemengde reaksie uitgelok. Daar was 'n groep navorsers wat positief op sy voorstelle gereageer het en tot 'n groot mate hulle eie benadering daarop gebaseer het. ${ }^{17}$ Daar was ook 'n groep navorsers wat nie met sy klassifikasie van die brief as 'n voorbeeld van forensiese retoriek saamgestem het nie en van mening was dat dit beter was om die brief as 'n vermenging van twee soorte retoriese genres te $\operatorname{sien}^{18}$ of selfs om dit as 'n voorbeeld van deliberatiewe

17 Voorbeelde: Brinsmead (1982); Ruegg (1983:5-37); Hester (1984:223-233) en Martin (1995:437-461).

18 Voorbeelde: Aune (1979:325-326 — 'n vermenging van forensiese en deliberatiewe retoriek) en Schoon-Janßen (1991:70-82; 112-113 — Gal 1:10-2:14 kan gesien word as suiwer forensiese retoriek; Gal 3:1-5:12 as 'n mengsel van deliberatiewe en forensiese retoriek en Gal 5:13-6:18 as suiwer deliberatiewe retoriek). 
retoriek te sien. ${ }^{19}$ Kritiek teen Betz en sy volgelinge se benadering het egter nie uitgebly nie. Besware is geopper teen die rigiede manier waarop hy antieke retoriek gebruik het, byvoorbeeld deur Classen (1992:319-344). Die skerpste kritiek het egter van Anderson en Kern gekom. Anderson (1996) het in 'n uitmuntende studie die swak teoretiese begronding van Betz en baie ander Nuwe-Testamentici se retoriese analises van Nuwe-Testamentiese tekste blootgelê. So wys hy byvoorbeeld daarop dat baie van hulle glad nie kennis neem van die feit dat daar geen eenvormige retoriese sisteem in die antieke was nie; dat hulle nie bewus is van die feit dat daar 'n groot verskil was tussen filosofiese retoriek (soos die van Aristotoles) en die soort retoriek wat in die retoriese skole beoefen is nie; en dat hulle nie besef dat retoriek in die praktyk baie meer soepel gebruik is as wat die fyn onderskeidings wat deur die leermeesters getref is, dit laat lyk nie (Anderson 1996:29-92). In sy studie het Kern (1998) soortgelyke ingrypende kritiek uitgespreek teen die veronderstelling dat Galasiërs as 'n voorbeeld van klassieke retoriek beskou kan word of dat dit deur middel van die antieke retoriese handboeke ontleed kan word.

Dit is egter belangrik om raak te sien dat Anderson en Kern nie teen 'n retoriese analise van die Galasiërbrief as sodanig is nie; bloot teen die wyse waarop sekere akademici antieke kategorieë op die brief afgeforseer het. Is daar 'n ander weg? Myns insiens wel. In plaas daarvan om 'n voorafgekose retoriese sisteem op die brief af te forseer, moet 'n mens liewer probeer om 'n retoriese analise vanuit die teks self te ontwikkel deur perikoop vir perikoop Paulus se retoriese strategie te rekonstrueer. Ek het onlangs so 'n poging voltooi (Tolmie 2004). Die resultate daarvan verskil heelwat van die resultate van die retoriese analises van Betz en ander. Betz het probeer aantoon dat 'n mens die brief as 'n stuk forensiese retoriek moet verstaan, dit wil sê as 'n exordium, narratio, propositio en probatio, gevolg deur' $\mathrm{n}$ exhortatio - alles geplaas binne 'n briefraamwerk. Myns insiens laat 'n mens veel meer reg geskied aan Paulus se retoriese strategie as die brief verstaan word in terme van 'n reeks opeenvolgende retoriese doelwitte wat hy probeer bereik, naamlik:

19 Voorbeelde: Kennedy (1984:144-145); Cosgrove (1988:25-27) en Smit (1989:126). 
1:1-2:10: Eerste doelwit: Oortuig die gehoor dat hy deur God geroep is en sy evangelie van Jesus Christus ontvang het.

2:11-3:14: Tweede doelwit: Oortuig die gehoor dat sy evangelie die ware evangelie is.

3:15-25: Derde doelwit: Oortuig die gehoor van die minderwaardigheid van die wet.

3:26-5:1: Vierde doelwit: Oortuig die gehoor dat die sogenaamde evangelie van sy opponente eintlik 'n vorm van geestelike slawerny verteenwoordig, en oorreed hulle om liewer geestelik vry te bly deur getrou te bly aan sy evangelie.

5:2-6:10: Vyfde doelwit: Oortuig die gehoor van die praktiese implikasies van sy evangelie binne hulle eie situasie: hulle moenie toegee aan die druk om hulle te laat besny nie, hulle moet die opponente vermy, en hulle moet hulle deur die Heilige Gees laat lei.

6:11-18: Sesde doelwit: Finale weerlegging van die opponente.

Nou terug na die belangrike vraag in hierdie artikel: "Wat is die impak van metodologie op ons verstaan van die Nuwe Testament?" Anders gestel: "Tot watter mate - indien enige - help die retoriese analise van Galasiërs ons om dié brief beter te verstaan?” Myns insiens bied 'n retoriese analise belangrike insigte vir die verstaan van die brief. Ek lig drie aspekte uit:

3.1 Die manier waarop Paulus se retoriese strategie hierbo verduidelik is, help om twee tekortkominge in Betz se analise reg te stel. Vanweë die manier waarop hy Paulus se argument ontleed, laat hy nie reg geskied aan Galasiërs 1-2 en 5-6 nie. Hy stel dit byvoorbeeld in soveel woorde dat hoofstukke 1 en 2 (synde die exordium en die narratio) slegs die aanloop tot Paulus se eintlike argument is wat in die probatio (3:1vv.) begin (Betz 1979:128). ${ }^{20}$ In die lig van die analise hierbo moet 'n mens so 'n siening afwys. Dit mag wel waar wees dat die meer "teologiese" deel van Paulus se argument in hoofstukke 3 en 4 lê, maar dit beteken nie dat die voorafgaande minder belangrik is nie. Inteendeel, vanuit retoriese hoek is die voorafgaande van

20 Longenecker (1990:128) en Becker (1992:292) stem hiermee saam. Volgens Longenecker is 3:1-4:11 "the most important argumentative section of Paul's letter", en volgens Becker is 3:1-5:12 "Zentrum der Darstellung”. 
deurslaggewende belang. Soos alle goeie redenaars plaas Paulus sy sterkste argumente eerste; daarom begin hy nie by die inhoud van sy evangelie nie. Hy begin by die feit dat hy deur God geroep is tot apostel en dat hy sy evangelie van Jesus Christus ontvang het. Dít is die deurslaggewende argument. As hy die Galasiërs dáárvan kon oortuig, was die res makliker. Indien hy hulle nie daarvan kon oortuig nie, sou die beste argumente oor die inhoud van die ware evangelie hulle in elk geval nie kon oortuig nie. Dus: Galasiërs 1-2 is allermins die blote aanloop tot Paulus se argument. Hy begin vanaf die heel eerste vers om te argumenteer en te oorreed.

Betz het ook heelwat probleme met hoofstukke 5:1-6:10 — primêr vanweë die feit dat die antieke handboeke nie voorsiening gemaak het vir exhortatio as onderdeel van 'n toespraak nie. Hy verbind Paulus se gebruik van paranese met die voorkoms van paranese in filosofiese briewe, maar dit oortuig nie. ${ }^{21}$ Indien die retoriese analise hierbo korrek is, hoef 'n mens nie na allerhande kunsmatige verklarings te gaan soek vir Paulus se gebruik van paranese nie. Dit vorm 'n logiese stap in die ontwikkeling van sy argument deurdat hy, nadat hy hulle oortuig het dat sy evangelie die korrekte een is, voortgaan om die praktiese implikasies vir die Galasiërs uit te lig, naamlik dat hulle nie moet toegee aan die druk om hulle te laat besny nie, hulle opponente moet vermy, en hulle deur die Heilige Gees moet laat lei.

3.2 'n Retoriese leesstrategie help 'n mens ook soms om verskynsels op mikrovlak te verklaar. As voorbeeld hiervan kan Paulus se benaming vir die Heilige Gees in Galasiërs 4:6 genoem word. Wanneer teoloë Paulus se siening van die Heilige Gees bespreek, noem hulle gewoonlik dat hy terme soos "die Gees", "die Gees van God" of "die Heilige Gees" verkies. In die verbygaan noem hulle dan die feit dat hy slegs een maal na die Gees verwys as "die Gees van sy Seun" sonder om verder ondersoek in te stel hoekom dit so is. ${ }^{22}$ Selfs kommentatore volstaan gewoonlik met die stelling dat dit die enigste plek is waar Paulus hierdie uitdrukking verkies. ${ }^{23}$ Vanuit retoriese perspektief kan 'n mens hierdie keuse verhelder. 'n Goeie redenaar struk-

21 Kyk ook die skerp kritiek deur Kern (1998:112-119).

22 Kyk byvoorbeeld Goppelt (1980:447) en Dunn (1997:263).

23 Kyk byvoorbeeld Bruce (1982:199); Betz (1979:210) en Martyn (1998:391). 
tureer sy argument tot in die fynste besonderhede — selfs tot op die vlak van woordkeuse. In hierdie geval moet 'n mens raaksien dat Paulus se retoriese strategie in hierdie perikoop primêr gerig is op die kontrastering van geestelike slawerny en geestelike kindskap (letterlik: "seunskap"). Hy tipeer die Gees in hierdie perikoop juis as

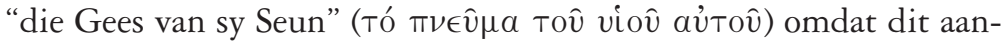
sluit by die klem wat die gedagte van "seunskap" in hierdie gedeelte kry. In vers 4 word Christus beskryf as die Seun van God (viós); in vers verwys hy na die Galasiërs se "aanneming tot seuns" (vio $\theta \in \sigma i ́ a)$ en in verse 6 en 7 word hulle beskryf as "seuns van God" (vioú). Dat dít juis bemiddel word deur die Heilige Gees word treffend verwoord en stilisties ondersteun as hy die Gees tipeer as "die Gees van sy Seun"!

Insig in Paulus se retoriese strategie help ons egter nie net op mikrovlak nie, maar ook om keuses te maak met belangrike teologiese implikasies. Die volgende voorbeeld illustreer dit.

3.3 Een van die aspekte in die Pauliniese teologie wat voortdurend opnuut onder die soeklig kom, is Paulus se siening van die wet. ${ }^{24}$ Een van die sake waaroor daar nie konsensus is nie, is of hy deurgaans in al sy briewe dieselfde siening oor die wet huldig. Daar is NuweTestamentici wat beweer dat hy nie konsekwent is nie en dat dit veral sigbaar is as 'n mens sy uitsprake oor die wet in Galasiërs en Romeine met mekaar vergelyk. As voorbeelde van Nuwe-Testamentici wat so 'n standpunt huldig, kan die standpunte van Hübner en Räisänen genoem word.

Volgens Hübner (1982) is die verskille tussen Paulus se uitsprake tussen Galasiërs en Romeine so ingrypend dat 'n mens dit glad nie met mekaar kan versoen nie. Die enigste manier om dit te verklaar is, om te aanvaar dat daar by Paulus 'n ontwikkeling in denke plaasgevind het: die skerp antinomistiese opvatting van Galasiërs is in Romeine vervang met 'n meer positiewe siening van die wet. In Hübner se eie woorde:

Während also in Röm der energische Versuch gemacht wird, den nomos als nomos Gottes (und somit Gott selbst) auf keinen Fall als sündenverursachendes Element erscheinen zu lassen, während also

24 Kyk byvoorbeeld Bonneau (1997:60-80); Pate (2000); Udo (2000:214-237) en Kim (2002:128-164). 
entschieden die Relation zwischen Gesetz und Sünde (zumindest primär) als Erkenntnisrelation bestimmt wird, schreibt Paulus in Gal unbefangen: Um (der Provokation) der Sündentaten willen wurde das Gesetz hinzugefügt ... Dem entspricht, daß Paulus in Gal das Gesetz als Engelgesetz diffamiert, während er in Rom größen Wert darauf legt, daß es heilig, gerecht und gut is $(7,12)$, da $\beta$ es geistlich ist (7:14), d.h. daß es auf die Seite Gottes, nicht aber auf die Seite des Gegenspielers Gottes, der hamartia, (6.22) gehört (Hübner 1982: 71-720).

Räisänen (1987) stel dit nog sterker: daar is geen innerlike logiese samehang tussen Paulus se uitsprake oor die wet nie; hy formuleer telkens ad hoc volgens die situasie. So byvoorbeeld onderskei Paulus volgens Räisänen (1987:23-27) nie duidelik tussen rituele en morele wet nie; weerspreek hy homself oor die vraag of die wet nog geldig vir gelowiges is (:42-80); sê hy in 3:15-20 dat die wet nie van God kom nie, maar in Romeine 7 en 8 dat dit wel van God kom (:128134); sê hy in Romeine 7:10 dat die wet gegee is om geestelike lewe bewerkstellig, maar in 3:21 dat die wet nie kan lewe gee nie (:150-3).

Nou is dit inderdaad waar dat daar opvallende verskille in Paulus se uitsprake oor die wet in Romeine en Galasiërs is. As 'n mens egter die verskillende retoriese situasies waarbinne Paulus die briewe dikteer, in gedagte hou, blyk dit dat die uitsprake nie teenoor mekaar staan nie. In die geval van Galasiërs is Paulus in 'n baie moeiliker situasie as in die geval van Romeine. As hy Galasiërs dikteer, is hy 'n desperate posisie, as't ware besig met 'n laaste dapper poging om die gelowiges in Galasië te oorreed om nie finaal te swig voor die aanslae van Joods-Christelike dwaalleraars en vryspraak deur geloof in Christus te verruil vir (gewaande) vryspraak deur gehoorsaamheid aan die Joodse wet nie. As hy Romeine dikteer, is die retoriese situasie baie gemakliker: hy veg nie verwoed teen een of ander dwaalleer nie, maar is vol verwagting dat 'n nuwe fase in sy bediening spoedig gaan aanbreek; hy het sy werk in die oostelike dele van die destydse wêreld afgehandel en beplan om in die westelike dele (o.a. Spanje) te gaan sendingwerk doen. Hiervoor sou die stad Rome as 'n goeie basis kon dien. Omdat die gelowiges in Rome hom nie persoonlik ken nie, dikteer hy die brief om seker te maak dat hulle "sy" evangelie korrek verstaan (Brown 1997:563-564). Dit is dus 'n baie gemakliker en minder beklemmende retoriese situasie waarin hy homself bevind. 
Verder is dit ook belangrik om raak te sien dat die verwysings na die wet in Galasiërs en Romeine nie binne dele voorkom met dieselfde retoriese oogmerk nie. Soos hierbo aangetoon, kom die meeste verwysings na die wet in Galasiërs voor in 'n gedeelte waarvan die retoriese doelstelling opgesom kan word as 'n poging om die Galasiërs te oortuig van die minderwaardigheid van die wet (3:15-25). Hy is nie besig met 'n gebalanseerde uiteensetting van die funksie van die wet nie. Hy is besig om polemies te reageer op die siening van sy opponente dat mense deur die wet vryspraak van die geloof kan verkry. Dat hy in die lig van hierdie retoriese doelstelling nie uitermate positief oor die wet is nie, is heeltemal verstaanbaar. In hierdie stadium in sy argument kan hy nie bekostig om te positief oor die wet te wees nie omdat dit sy eie saak sal benadeel en dalk juis die verkeerde idees wat die Galasiërs begin aanhang het, verder sal versterk. Later, as hierdie deel van die argument afgehandel is, kan hy wel positief oor die wet praat, as hy die Galasiërs oproep om mekaar se laste te dra en so die "wet van Christus" te vervul (6:2).

In die geval van die Romeinebrief kom die positiewe uitsprake oor die wet nie voor in 'n gedeelte wat handel oor die vraag of 'n mens vryspraak deur die wet kan verkry of nie. Dit gaan oor iets anders, naamlik die feit dat die wet wat deur God gegee is, nog steeds deur sonde en dood misbruik word - iets wat elke gelowige voortdurend ervaar. ${ }^{25}$ Die vraag is nie "Hoe verkry ek God se vryspraak nie?", maar wel "Hoekom leef ek nie soos God wil hê nie?" Dat Paulus nou baie positiewer oor die wet kan praat, is verstaanbaar en hoef nie gesien te word as 'n verdere ontwikkeling in sy teologie of selfs as 'n inkonsekwentheid in sy teologie nie. Die verskil in retoriese situasie en doelstelling verklaar dit.

'n Laaste opmerking. Soos hierbo aangetoon, is beide Hübner en Räisänen van mening dat Paulus in Galasiërs sê dat die wet nie deur God gegee is nie. Hübner (1982:29-30) beweer selfs dat Paulus sê dat wet nie van God af kom nie, maar wel van engele - bose demoniese wesens wat nie geïnteresseerd was in die mense se verlossing nie, maar hulle net wou verslaaf. Hy baseer sy siening op 3:19 en

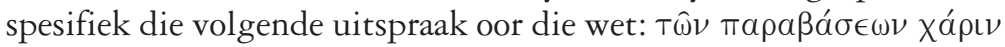

25 Kyk byvoorbeeld Dunn (1998:374) en Wilckens (1979:73). 


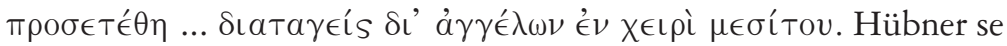
interpretasie van hierdie vers is egter hoogs onwaarskynlik. Daar is byvoorbeeld geen rede om die twee passiewe ( nie as goddelike passiewe te interpreteer nie. Vanuit retoriese perspektief kan 'n mens nog iets byvoeg: om die Galasiërs (wat waarskynlik 'n redelike kennis van die Ou Testament gehad het) te probeer oortuig dat die wet nie van God afkomstig is nie, maar wel van bose engele, sou retories gesien so 'n onoordeelkundige stap wees dat dit moeilik versoenbaar is met die vernuftige wyse waarop Paulus sy argumente in die res van die brief kies en aanbied. Hy sou homself beslis nie so in die voet skiet nie!

\section{KONKLUSIE}

Aan die begin van hierdie artikel het ek die vraag gevra of al die nuwe metodes wat tot beskikking van Nuwe-Testamentici gekom het ons inderdaad help om die Nuwe Testament beter te verstaan. Ek vertrou dat ek daarin geslaag het om te wys wat die impak van metodologie op ons verstaan van die Nuwe Testament kan wees. Meer spesifiek: dat 'n mens deur die verantwoordelike gebruik van nuwere leesstrategieë nuwe fasette in die Nuwe Testament kan ontdek of andersins beter verantwoorde keuses oor moeilike sake kan maak. 


\section{BIBLIOGRAFIE}

\section{ANDERSON R D}

1996. Ancient rhetorical theory and Paul. Kampen: Kok Pharos.

Aune D E

1981. Resensie van H. D. Betz, Galatians. A commentary on Paul's Letter to the churches in Galatia (Philadelphia: Fortress, 1979). RStR 7:323-325.

\section{BARRETT C K}

1978. The Gospel according to John. An introduction with commentary and notes on the Greek text. London: SPCK.

\section{BECKER J}

1992. Paulus. Der Apostel der Völker. Tübingen: Mohr-Siebeck.

\section{BETZ H D}

1975. The literary composition and function of Paul's Letter to the Galatians. NTS 21(3):353-379.

1979. Galatians. A commentary on Paul's Letter to the churches in Galatia. Philadelphia: Fortress.

BONNEAU N

1997. The logic of Paul's argument on the curse of the law in Galatians 3:1014. NT 39(1):60-80.

\section{BRINSMEAD B H}

1982. Galatians - Dialogical response to opponents. Chico: Scholars Press.

\section{BROWN R E}

1984. The Gospel according to John. Garden City: Doubleday.

1997. An introduction to the New Testament. New York: Doubleday.

\section{Brown R E, Donfried K P \& Reumann J}

1973. Der Petrus der Bibel. Eine ökumenische Untersuchung. Stuttgart: Calwer.

\section{BRUCE F F}

1982. The Epistle to the Galatians. A commentary on the Greek text. Grand Rapids: Eerdmans.

\section{BuSSE U}

2002. Das Johannesevangelium. Bildlichkeit, Diskurs und Ritual. Leuven: University Press/Uitgeverij Peeters.

\section{Chatman S}

1978. Story and discourse. Narrative structure in fiction and film. Ithaca: Cornell.

\section{Classen C J}

1992. St. Paul's epistles and ancient Greek and Roman rhetoric. Rhetorica 19(4): 319-344. 


\section{Cosgrove C H}

1988. The cross and the spirit. A study in the argument and theology of Galatians. Macon: Mercer University Press.

\section{Cullmann O}

1970. Petrus. Jünger. Apostel. Märtyrer. Zürich: Theologischer Verlag.

\section{Culpepper R A}

1983. Anatomy of the Fourth Gospel. A study in literary design. Philadelphia: Fortress.

Du RAND J A

1990. Johannese perspektiewe. Inleiding tot die Johannese geskrifte. Pretoria: Orion.

\section{Du TOIT A B}

1993a. Die opkoms en huidige stand van die Nuwe-Testamentiese ondersoek in Suid-Afrika: Deel 1. HTS 49:503-514.

1993b. Die opkoms en huidige stand van die Nuwe-Testamentiese ondersoek in Suid-Afrika: Deel 2. HTS 49:787-809.

\section{DunN J D G}

1997. The theology of Paul the apostle. Edinburg: T \& T Clark.

1998. Romans 1-8. Dallas: Word Books.

\section{GOPPELT L}

1980. Die Theologie des Neuen Testaments. Göttingen: Vandenhoeck \& Ruprecht.

\section{Hester J D}

1984. The rhetorical structure of Galatians 1:11-2:14. JBL 103(2):223-233.

\section{HÜBNER H}

1982. Das Gesetz bei Paulus. Ein Beitrag zum Werden der paulinischen Theologie (Dritte Auflage). Göttingen: Vandenhoeck \& Ruprecht.

\section{KENNEDY G A}

1984. New Testament interpretation through rhetorical criticism. Chapel Hill: University of North Carolina Press.

\section{KERN P H}

1998. Rhetoric and Galatians. Assessing an approach to Paul's Epistle. Cambridge University Press.

\section{KIM S}

2002. Paul and the new perspective. Second thoughts on the origin of Paul's gospel. Tübingen: Mohr-Siebeck.

\section{LONGENECKER R N}

1990. Galatians. Dallas: Word.

\section{MARTIN T}

1995. Apostasy to paganism: the rhetorical stasis of the Galatian controversy. JBL 114(3):437-461. 
MARTYN J L

1998. Galatians. A new translation with introduction and commentary. New York:

Doubleday.

MAYNARD A H

1984. The role of Peter in the Fourth Gospel. NTS 30:531-548.

PATE C

2000. The reverse of the curse. Paul, wisdom, and the law. Tübingen: Mohr-Siebeck.

QUAST K

1989. Peter and the Beloved Disciple: figures for a community in crisis. Sheffield: JSOT Press.

RÄISÄNEN H

1987. Paul and the law. Tübingen: Mohr-Siebeck.

\section{RIMMON-KENAN S}

1983. Narrative fiction: contemporary poetics. London: Metheuen.

\section{RUEGG U}

1983. Paul et la rhétorique ancienne. BullCentProtEtud 35(7-8):5-35.

\section{SCHNACKENBURG R}

1979. Das Johannesevangelium. Freiburg: Herder.

\section{SCHOON-JANßEN J}

1991. Umstrittene Apologien in den Paulusbriefen. Studien zur rhetorischen Situation des

1. Thessalonicherbriefes, des Galaterbriefes und des Philipperbriefes. Göttingen: Vandenhoeck \& Ruprecht.

\section{SMIT J}

1989. The Letter of Paul to the Galatians: a deliberative speech. NTS 35(1):126.

STALEY J L

1988. The print's first kiss: a rhetorical investigation of the implied reader in the Fourth Gospel. Atlanta: Scholars Press.

\section{STIBвE M W G}

1992 John as storyteller. Narrative criticism and the Fourth Gospel. Cambridge: Cambridge University Press.

1993. John. Sheffield: JSOT Press.

\section{TOlmie D F}

1999. Narratology and biblical narratives. A practical guide. San Francisco: ISP. 2000: Retoriese analises van die Brief aan die Galasiërs: 'n Oorsig. In: D. F. Tolmie (red.), Kaleidoskoop. Artikels oor Teologie. Gedenkuitgawe Fakulteit Teologie UOVS 1980-2000 (Acta Theologica Supplementum 1), 147-168.

2004. A rhetorical analysis of the Letter to the Galatians. Unpublished Ph.D. dissertation. Bloemfontein: University of the Free State. 


\section{UDOH F}

2000. Paul's views on the law: questions about origin (Gal. 1:6-2:21; Phil. 3:211). NT 42(3):214-237.

\section{VAN DER WATT J G}

2000. Family of the King: dynamics of metaphor in the Gospel according to John. Leiden/ Boston: Brill.

\section{VAN ZYL H C}

2000 Die stand van Nuwe-Testamentiese navorsing in Suid Afrika. Enkele tendense in die jare 1993-1999. In: D. F. Tolmie (red.), Kaleidoskoop. Artikels oor Teologie. Gedenkuitgawe Fakulteit Teologie UOVS 1980-2000 (Acta Theologica Supplementum 1), pp. 169-237.

WIARDA T

2000. Peter in the Gospels. Tübingen: Mohr-Siebeck.

\section{WILCKENS U}

1979 Der Brief an die Römer. Zürich: Benziger.

Trefwoorde

Nuwe-Testamentiese eksegese

Narratologie

Johannesevangelie

Retoriek

Brief aan die Galasiërs
Keywords

New Testament exegesis

Narratology

Gospel according to John

Rhetoric

Letter to the Galatians 